\title{
Seed Priming with Nano Boron Nitride Increases the Performance of Sunflower (Helianthus annuus L.) Seedlings
}

\author{
K.N. Geetha ${ }^{1}$, Kavita Mahadev Goudar ${ }^{1}$, N.N. Lingaraju ${ }^{1 *}$, \\ Ramesh Raddy ${ }^{2}$ and A.G. Shankar ${ }^{2}$ \\ ${ }^{I}$ Department of Agronomy, ${ }^{2}$ Department of Crop Physiology, UAS, GKVK, Bengaluru, \\ Karnataka, India \\ *Corresponding author
}

\section{A B S T R A C T}

A laboratory investigation was initiated to examine the effect of "Seed priming with nano

Keywords

Borax, Nano-boron nitride, Sunflower, Seed priming

Article Info

Accepted:

04 October 2018

Available Online:

10 November 2018 boron nitride increases the performance of sunflower (Helianthus annuus L.) seedlings" at Department of Agronomy, University of Agricultural Sciences, GKVK, Bengaluru. The experiment was arranged in completely randomized design with five replications. Boron nitride (particle size $70 \mathrm{~nm}$ ) is used as source of nano boron and Borax [sodium tetraborate $\left(\mathrm{Na}_{2} \mathrm{~B}_{4} \mathrm{O}_{7} \cdot 10 \mathrm{H}_{2} \mathrm{O}\right)$ ] was used as a source of boron. The treatments consist of seed priming with borax at $0 \%, 0.2 \%, 0.4 \%, 0.5 \%$ and $0.6 \%$ borax and nano boron. Significantly higher seed germination $(88.3 \%)$, root length $(5.65 \mathrm{~cm}$ and $11.4 \mathrm{~cm}$ respectively), shoot length $(7.35 \mathrm{~cm}$ and $18.14 \mathrm{~cm}$ respectively) and vigour index (1286 and 1773, respectively) at 8 and 15 days after sowing were recorded in seed treatment with nano boron at $0.2 \%$ seed priming. Significantly lower seed germination $(76.7 \%)$, root length $(0.58 \mathrm{~cm}$ and $1.28 \mathrm{~cm}$ respectively), shoot length $(1.03 \mathrm{~cm}$ and $5.66 \mathrm{~cm}$ respectively) and vigour index (121 and 532 respectively) at 8 and 15 days after sowing were recorded in seed priming with $0.6 \%$ borax treatment.

\section{Introduction}

The cultivated sunflower (Helianthus annuus L.) is native of southern United States and Mexico, during later part of 20th century, the crop was introduced to India. Seed contains the oil varying from $35-43 \%$.

The unsaturated fatty acids such as oleic and linoleic comprise about $90 \%$ of the total. India ranks fourth in area coverage of sunflower, but the production-wise it ranks eighth due to very low productivity compared to other countries.
Karnataka, Andhra Pradesh and Maharashtra are the major sunflower growing states contributing about $91 \%$ and $82 \%$ of the countries area and production, respectively (Rai et al., 2016).

Main reasons for low productivity of sunflower are poor seed setting and high percent of chaffy seeds in the centre of capitulum. The reasons for poor seed setting are self-incompatibility, absence of pollen vectors, nutrient imbalance, less irrigation and low soil fertility. Reddy et al., (2003) reported 
that inadequate and imbalanced nutrient supply is the reason for low productivity of sunflower. In recent years, micronutrient deficiencies and their impact on crop yields are widely reported in various parts. Among different micronutrient deficiency, boron deficiency is the second most dominant problem globally. Boron deficiency has been reported in 80 countries around the world and in 132 crops. Sunflower is one of the most sensitive crops to low boron supply and required high amount of boron as compared to other crops and has been used as a good indicator of boron deficiencies.

Seed priming is the process of regulating germination by managing the temperature and seed moisture content in order to maximize the seed's potential. Several different priming methods have been reported to be used commercially, including liquid or osmotic priming and solid matrix priming. Nano priming of micronutrients is a new method for improving germination percentage and seedling vigour (Dehkourdi and Mosavi, 2013; Ghafari and Razmjoo, 2013). The amount of nano boron nitride fertilizer required is very less in quantity compared to foliar application.

Boron especially that manufactured via nanotechnology system has many merits, the first is the quick and easily uptake by plants. Such form has lower tendency to leach via soil and appear its impact for shorter times.

In general, boron is responsible for enhancing cell division, pollination and fertilization of flowers, pollen germination, uptake of water and various nutrients, the resistance of plants to various disorders as well as the biosynthesis and translocation of sugars (Gauch and Dugger, 1953; Nijjar, 1985). The optimum quantity range of boron application is rather narrow, because high concentrations of boron become toxic to plants (Goldberg and Glaubig, 1985).

\section{Materials and Methods}

A laboratory studies were undertaken at Department of Agronomy, University of Agricultural Sciences, GKVK, Bengaluru to investigate the effect of nano boron seed priming on seed germination, seedling length and seedling vigour of sunflower (Helianthus annuus L.). The experiments were arranged in completely randomized design with five and nine treatments replicated five times $V i z ., \mathrm{T}_{1}$ Control, $\mathrm{T}_{2}-0.2 \%$ nano boron seed priming, $\mathrm{T}_{3^{-}}-0.4 \%$ nano boron seed priming, $\mathrm{T}_{4}-0.5 \%$ nano boron seed priming, $\mathrm{T}_{5^{-}} 0.6 \%$ nano boron seed priming, $\mathrm{T}_{6}-0.2 \%$ borax seed priming, $\mathrm{T}_{7}-0.4 \%$ borax seed priming, $\mathrm{T}_{8}-0.5$ $\%$ borax seed priming, $\mathrm{T}_{9}-0.6 \%$ borax seed priming.

Boron nitride (as a source of nano boron which is having particle size of $70 \mathrm{~nm}$ ) and borax [sodium tetraborate $\left(\mathrm{Na}_{2} \mathrm{~B}_{4} \mathrm{O}_{7} \cdot 10 \mathrm{H}_{2} \mathrm{O}\right)$ ] was used as a source of boron. Since bulk boron nitride $(\mathrm{BN})$ nano fertilizer will not dissolve in water and plants cannot absorb it, the materials were suspended directly in hot deionised water and dispersed by ultrasonic vibration (100 W, $40 \mathrm{KHz}, 68$ amplitude) for 15 minutes. The nano scale suspensions appear as clear solutions. The $\mathrm{pH}$ of all the prepared suspension was found to be 6.5-7.0. An absolute control was also maintained. Petri dishes with filter papers were used for sowing of seeds.

Filter papers were well soaked by adding distilled water and ten seeds were uniformly placed per Petri dish ( $9.5 \mathrm{~cm}$ diameter) using a forceps. All the petri dishes were covered with lids and kept at room temperature $\left(28 \pm 2^{\circ} \mathrm{C}\right)$. Germination continued for seven days and germinated seeds were counted fourth day after sowing. Parameters such as shoot length, root length were recorded using a measuring scale after 8 and 15 days after sowing respectively. 


\section{Results and Discussion}

One of the main reasons of low yield of the sunflower is the deficiency of micronutrients. The use of essential micronutrients in the right proportion and optimum quantity is the key to boost and sustain crop productivity.

Among micronutrient deficiency, boron deficiency is the second most dominant problem in the world, which is involved in the reduction of sunflower production by so many reasons.

\section{Laboratory studies I}

Significantly higher seed germination (94\%) was recorded in seed treatment with nano boron@0.2\% seed priming over all other treatments. However, Significantly lower seed germination was recorded with control (80.9 $\%$ ) it was on par with seed priming with $0.4 \%$ nano boron $(85.5 \%), 0.4 \%$ borax $(84.4 \%)$ and $0.2 \%$ borax $(81.8 \%)$.

Different nano boron and borax treatments significantly influenced the root length at 8 and 15 DAS (Table 1). Significantly higher root length was recorded with nano boron $0.2 \%$ seed priming (6.56, $11.91 \mathrm{~cm}$ respectively) at 8 and 15 DAS.

Lower root length was recorded with control $(3.72 \mathrm{~cm})$ at 8 DAS and $0.2 \%$ borax seed treatment at 15 DAS $(5.93 \mathrm{~cm})$ followed by control $(6.84 \mathrm{~cm})$. The data revealed that there was a significant difference with respect to shoot length at 8 DAS and 15 DAS as influenced by different levels of nano boron and borax seed priming (Table 1).

Significantly higher shoot length was recorded with treatment $0.2 \%$ nano boron $(7.58 \mathrm{~cm}$ and $12.71 \mathrm{~cm}$, respectively) at 8 and 15 DAS. Lower shoot length was recorded with $0.4 \%$ borax $(2.60 \mathrm{~cm})$ at 8 DAS and $0.2 \%$ borax
$(7.87 \mathrm{~cm})$ at 15 DAS. Seed treatment with nano boron and borax at different levels showed a significant influence on seedling vigour index at 8 and 15 DAS (Table 4.2). The maximum seedling vigour index was recorded with $0.2 \%$ nano boron (1329 and 2314 plant $^{-1}$ respectively). Significantly lower seedling vigour index was recorded with $0.4 \%$ borax seed priming (555 plant $\left.^{-1}\right)$ at 8 DAS and $0.2 \%$ borax (1129 plant $\left.^{-1}\right)$ at 15 DAS.

\section{Laboratory studies-II}

Results showed that higher seed germination was recorded with $0.2 \%$ nano boron seed priming $(88.33 \%)$ compared to control (75.0 $\%$ ) (Table 2; Plate 1 and 2). Seed priming with nano boron@ $0.2 \%$ recorded maximum root length $(5.65 \mathrm{~cm}$ and $11.38 \mathrm{~cm})$ and shoot length $(7.35 \mathrm{~cm}$ and $18.14 \mathrm{~cm})$ at 8 and 15 DAS respectively. However, the root length and shoot length were decreased significantly with the increase in borax concentration. The lowest root length $(0.58 \mathrm{~cm}$ and $1.28 \mathrm{~cm}$, respectively) and shoot length $(1.03 \mathrm{~cm}$ and $5.66 \mathrm{~cm}$, respectively) were recorded in seed priming with borax @ $0.6 \%$ which was on par with $0.5 \%$ borax seed priming.

The decrease in root and shoot length was mainly due to boron at higher levels which inhibits root and shoot growth primarily through limiting cell elongation and cell division (Brown et al., 2002). Maximum seedling vigour was recorded with $0.2 \%$ nano boron seed priming (1145 plant $^{-1}$ and 2608 plant $^{-1}$ ) at 8 and 15 DAS respectively. This was mainly due to the increased germination percentage, root length and shoot length of sunflower seedlings. Significantly lower seedling vigour index was recorded at seed treatment with borax @ $0.6 \%$ (121 and 532 plant $^{-1}$ respectively) at 8 and 15 DAS. The results are in conformity with the findings of Habtamu Ashagre et al., (2014) and Prathima et al., (2016). 
Table.1 Germination, root length, shoot length and vigour index of sunflower seedling as influenced by different levels of nano boron and borax seed treatment (8 and 15 DAS, lab studies DOS: 03.09.2016 - 17.10.2016)

\begin{tabular}{|c|c|c|c|c|c|c|c|}
\hline \multirow[t]{2}{*}{ Treatments } & \multicolumn{4}{|c|}{8 DAS } & \multicolumn{3}{|c|}{15 DAS } \\
\hline & $\begin{array}{c}\text { Germination } \\
\%\end{array}$ & $\begin{array}{l}\text { Root length } \\
(\mathrm{cm})\end{array}$ & $\begin{array}{l}\text { Shoot length } \\
(\mathrm{cm})\end{array}$ & Vigour index & $\begin{array}{l}\text { Root length } \\
\text { (cm) }\end{array}$ & $\begin{array}{c}\text { Shoot length } \\
(\mathrm{cm})\end{array}$ & Vigour index \\
\hline Control & 80.9 & 3.72 & 6.88 & 858 & 6.84 & 9.06 & 1286 \\
\hline 0.2 \% Nano Boron & 94.0 & 6.56 & 7.58 & 1329 & 11.91 & 12.71 & 2314 \\
\hline $0.4 \%$ Nano Boron & 85.5 & 4.06 & 6.80 & 928 & 8.16 & 9.67 & 1524 \\
\hline $0.2 \%$ Borax & 81.8 & 3.79 & 4.11 & 646 & 5.93 & 7.87 & 1129 \\
\hline $0.4 \%$ Borax & 84.4 & 3.98 & 2.60 & 555 & 8.80 & 8.85 & 1489 \\
\hline S Em \pm & 1.68 & 0.09 & 0.12 & 18.1 & 0.16 & 0.21 & 26.62 \\
\hline $\mathrm{CD}(\mathrm{P}=0.01)$ & 6.98 & 0.37 & 0.48 & 74.7 & 0.66 & 0.88 & 109.95 \\
\hline CV $(\%)$ & 4.42 & 4.52 & 4.65 & 4.68 & 4.29 & 4.92 & 3.86 \\
\hline
\end{tabular}

Table.2 Germination, root length, shoot length and vigour index of sunflower seedling as influenced by different levels of nano boron and borax seed treatment (8 and 15 DAS, lab studies DOS: 3.01. 2017 - 18.01.2017)

\begin{tabular}{|c|c|c|c|c|c|c|c|}
\hline \multirow{2}{*}{ Treatments } & \multicolumn{4}{|c|}{8 DAS } & \multicolumn{3}{|c|}{15 DAS } \\
\hline & $\begin{array}{c}\text { Germination } \\
(\%)\end{array}$ & $\begin{array}{l}\text { Root length } \\
\text { (cm) }\end{array}$ & $\begin{array}{l}\text { Shoot length } \\
\text { (cm) }\end{array}$ & Vigour index & $\begin{array}{l}\text { Root length } \\
\text { (cm) }\end{array}$ & $\begin{array}{l}\text { Shoot length } \\
\text { (cm) }\end{array}$ & Vigour index \\
\hline Control & 75.0 & 3.25 & 6.37 & 717 & 7.43 & 14.30 & 1619 \\
\hline $0.2 \%$ Nano Boron & 88.3 & 5.65 & 7.35 & 1145 & 11.4 & 18.14 & 2608 \\
\hline $0.4 \%$ Nano Boron & 81.7 & 4.48 & 6.52 & 901 & 8.24 & 15.91 & 1973 \\
\hline $0.5 \%$ Nano Boron & 78.3 & 3.90 & 6.05 & 781 & 5.08 & 13.53 & 1457 \\
\hline $0.6 \%$ Nano Boron & 81.7 & 3.01 & 6.49 & 777 & 4.25 & 12.13 & 1338 \\
\hline $0.2 \%$ Borax & 85.0 & 2.36 & 3.56 & 503 & 4.89 & 14.35 & 1631 \\
\hline $0.4 \%$ Borax & 86.7 & 3.15 & 4.53 & 668 & 8.53 & 14.48 & 1992 \\
\hline $0.5 \%$ Borax & 78.3 & 0.48 & 0.93 & 109 & 1.30 & 5.75 & 550 \\
\hline $0.6 \%$ Borax & 76.7 & 0.58 & 1.03 & 121 & 1.28 & 5.66 & 532 \\
\hline S Em & 2.02 & 0.14 & 0.09 & 16.6 & 0.27 & 0.26 & 36.8 \\
\hline $\mathrm{CD}(P=0.01)$ & 7.98 & 0.57 & 0.34 & 65.5 & 1.05 & 0.99 & 146 \\
\hline $\mathrm{CV}(\%)$ & 4.97 & 9.62 & 4.084 & 5.21 & 9.11 & 4.52 & 4.84 \\
\hline
\end{tabular}




\begin{tabular}{lllll}
$0.2(\%)$ & $0.4(\%)$ & $0.5(\%)$ & $0.6(\%)$ & Control \\
\hline
\end{tabular}

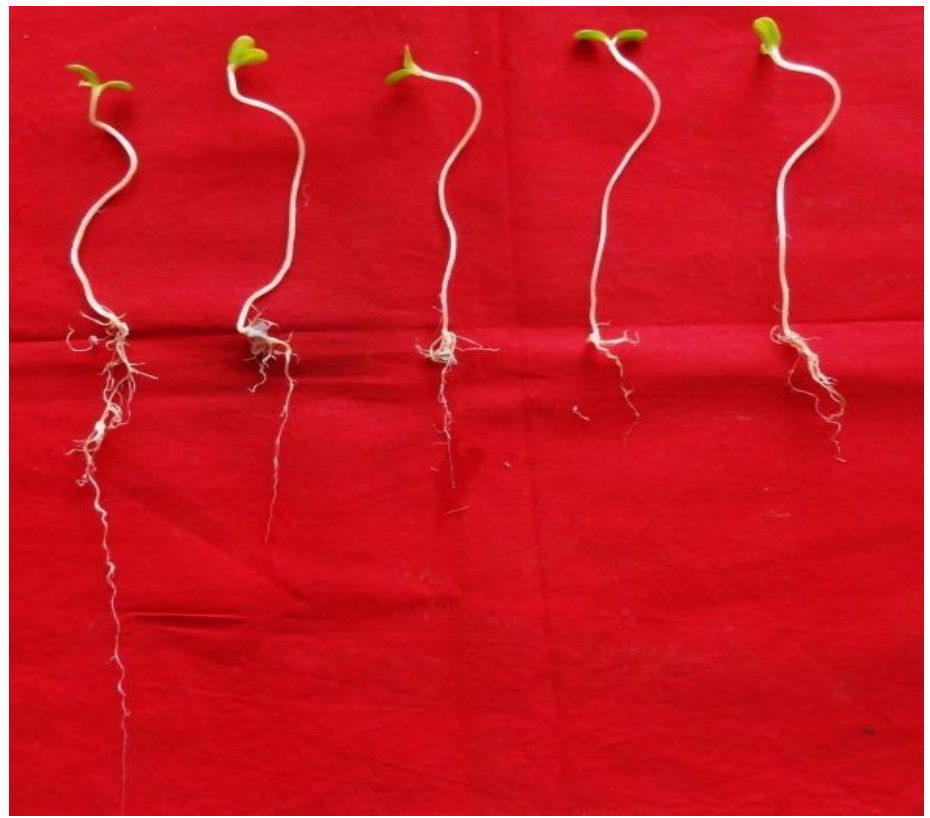

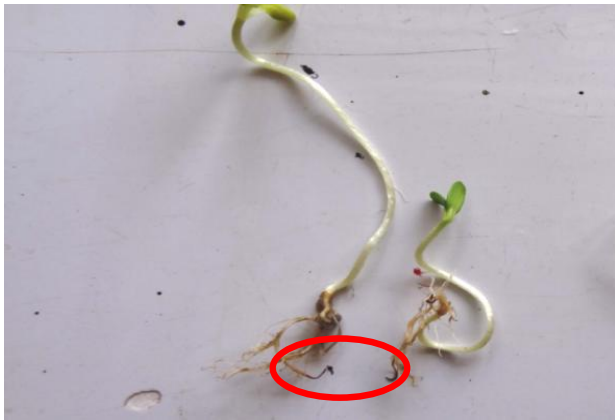

0.5 \% Nano Boron and Borax

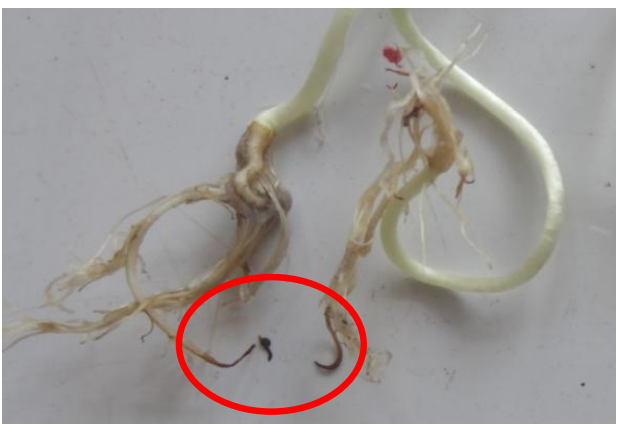

$0.5 \%$ Nano Boron and Borax

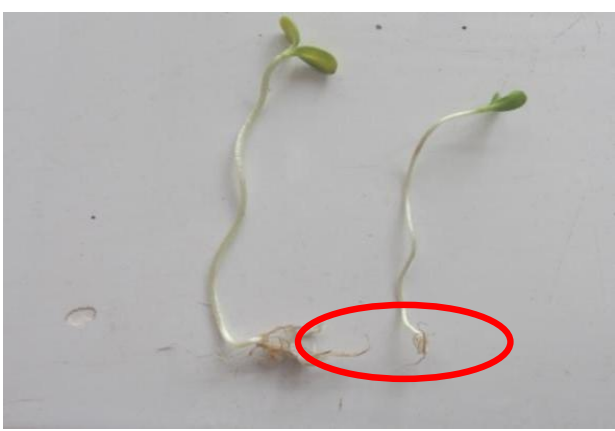

$0.5 \%$ and $0.6 \%$ Nano Boron

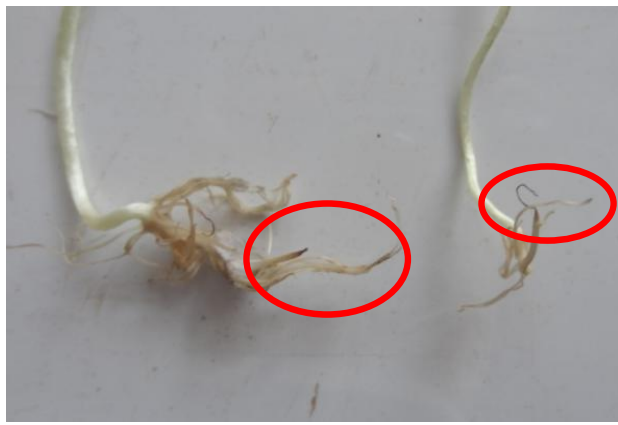

$0.5 \%$ and $0.6 \%$ Nano Boron

Plate 2: Toxic effect of nano boron treated seedling at 22 days after sowing in petriplates 


\section{Tolerance assay}

\section{Root growth inhibition of sunflower seeds by boron nano particles and borax}

In order to develop comprehensive toxicity profile for nano boron particles, their phytotoxicity- the ability to cause injury to plants was also investigated.

Our study examined the effect of five levels of nanoparticles on seed germination (Table 2) and seedling growth of sunflower crop and also observed that higher levels of the nano boron particles had inhibition on root growth of the sunflower seedlings (Blackening of the root tips: Plate 2).

This study confirms the toxicity levels of nano boron use in sunflower or inhibition of sunflower seedling growth (root growth) by boron nano particles.

Seed priming with nano boron $0.2 \%$ showed an increase in germination percentage, root and shoot length. Germination per cent, shoot and root length decreased significantly with further increase in nano boron concentrations $(0.5 \%$ and $0.6 \%$ ).

\section{References}

Brown, P. H., Bellaloui, N., Wimmer, M., Bassil, E. S., Riuz, J., Hu, H., Pfeffer, H., Dannel, F. and Romheld, V., 2002, Boron in plant biology. Plant Biol., 4: 205-227.

Dehkourdi, E. and Mosavi, M., 2013, Effect of anatase nanoparticles $\left(\mathrm{TiO}_{2}\right)$ on parsley seed germination (Petroselinum crispum) in vitro. Biological Trace Element Research.155: 283-286.
Fariduddin, Q., Hayat, S. and Ahmad, A., 2003, Salicylic acid influences net photosynthetic rate, carboxylation efficiency, nitrate reductase activity and seed yield in Brassica Juncea. Photosynthetica, 41: 281284.

Gauch, H.G. and Dugger, W. M., 1953, The role of boron in the translocation of sucrose. Plant Physiology, 28: 457-766.

Ghafari, H. and Razmjoo, J., 2013, Effect of foliar application of nano-iron oxidase, iron chelate and iron sulphate rates on yield and quality of wheat. International Journal of Agronomy and Plant Production, 4(11): 2997-3003.

Goldberg, S. and Glaubig, R. A., 1985, Boron absorption on aluminium and iron oxide minerals. Soil Sci. Soc. American J., 49: 1374-1379.

Habtamu Ashagre, Ibrahim, A. H., Urgecha Fita and Ermias Estifanos, 2014, Boron toxicity on seed germination and seedling growth of safflower (Carthamus tinctorius L.). Herald J. Agri. Food Sci. Res., 3(1): 1-6.

Nijjar, G. S., 1985, Nutrition of Fruit, Trees. Kalyani Publishers, New Delhi, India, p. 100.

Prathima, A. S., Rohini N Met and Shivaramu, H. S., 2016, Influence of boron seed treatment on seed germination, seedling length and seedling vigor in sunflower (Helianthus annuus L.). Int. J. Sci. Nature, 7(2):273276.

Rai, S. K., Deeksha Charak and Rajeev Bharat, 2016, Scenario of oilseed crops across the globe. Plant Archives, 16 (1): 125-132.

Reddy, S. S., Yadahalli, Y. H., Kumar, V. K. K., Kumara, O. and Naik, A. H. K., 2003, Effect of fertilizer, gypsum and boron application on yield and economics of sunflower hybrids. Crop Res., 23(3): 450453.

\section{How to cite this article:}

Geetha, K.N., Kavita Mahadev Goudar, N.N. Lingaraju, Ramesh Raddy and Shankar, A.G. 2018. Seed Priming with Nano Boron Nitride Increases the Performance of Sunflower (Helianthus annuus L.) Seedlings. Int.J.Curr.Microbiol.App.Sci. 7(11): 503-508. doi: https://doi.org/10.20546/ijcmas.2018.711.060 